\title{
The Causes and Effects of Tropical Deforestation
}

\author{
Leslie Campbell
}

\author{
Department of Physical and Environmental Sciences, University of Toronto, Scarborough, \\ 1265 Military Trail, Toronto, ON, M1C 1A4 \\ lesliecampbell@gmail.com
}

\begin{abstract}
Tropical rainforest deforestation is a major problem in many tropical regions and can have major impacts on system ecology and long term soil productivity. This paper examines the trend of increased colonization of tropical rainforest regions and the resulting effects on long term natural system productivity in these areas. It also explores the impact of conventional agricultural practices, the majority of which were developed in temperate climates, when employed in a tropical context. International trends in the consumption of imported tropical wood and rainforest products are also suggested as a major culprit for increased tropical deforestation. Reduction in international rainforest product consumption and greater awareness on the part of Western consumers as to the impacts of tropical deforestation are suggested as potential solutions to reduce this problem.
\end{abstract}

\section{Key words: rainforest, effect, deforestation}

Tropical rainforests are some of the most biodiverse regions on the planet supporting the vast majority of animal and plant species. Unfortunately, they are disappearing at an alarming rate due to human activity. This essay will examine the various reasons for the settlement of tropical rainforest regions such as Amazonia and illustrate why the clearing of these forests for activities such as sedentary agriculture is a venture with little prospect of success. The developed world is partially responsible for the widespread destruction of the tropical rainforests and has a responsibility to help to alleviate pressure on these delicate yet crucially important ecosystems.

There are a wide variety of different forces propelling settlers to colonize tropical rainforest regions. For one, a growing emphasis on national development encourages countries with tropical rainforest to explore their untapped resources (Skole et al, 1994). Government programs aimed at poverty alleviation through resettlement programs also provide incentive for the poor to colonize rainforest regions. Furthermore, because unequal land distribution in many tropical regions means that much of the population does not own their own land, colonizing the rainforest can offer the opportunity for poverty stricken individuals to own land and be selfsufficient. This is exemplified in Brazil, where 4.5 per cent of the population controls 81 per cent of the land area. (Park, 1992). The lure of valuable natural resources is also causing more and more settlement in rainforest regions. A general push by developing countries toward import substitution industrialization in an attempt to boost self sufficiency and economic prosperity 
has meant that it is increasingly profitable to extract resources from tropical rainforests (Goodman and Hall, 1990). Mining precious metals such as tin, iron and gold, while incredibly environmentally damaging, holds economic potential which draws settlers (Hemming, 1985). The extraction of rainforest timber is also a lucrative business in the rainforest. This is due to the fact that tropical woods such as mahogany are both incredibly valuable on the international market, and relatively cheap to harvest (Park, 1992). Logging operations have played a major role in the deforestation of the rainforests in much of Asia, and have been practiced so extensively in regions of Africa that many countries are now devoid of useable timber (Park, 1992). The combination of these social and economic incentives has led to increased settlement of tropical rainforest regions, and is compounding the damage done to tropical rainforests.

These settlement patterns indirectly threaten the safety of the rainforests because they often lead to deforestation. Currently, much of the cleared land is for food production in the form of sedentary agriculture. This is a strategy that has little prospect of success due to the nature of the tropical rainforest environment. In order to explain why, it is necessary to understand how a healthy rainforest system operates.

Chemical analysis of rainforest soils has indicated that they are generally lacking in nutrients (Hemming, 1985). This is because these areas have been undisturbed by glaciation for thousands of years. In these mature forests, soluble substances have been washed out of the soil by leaching over thousands of years leaving the soils very infertile (Hemming, 1985). Rainforest ecosystems have adapted to the low nutrient levels in the soil by cycling nutrients within their systems in a strictly closed cycle. Trees have wide shallow root systems allowing them to quickly absorb what little nutrients there are near the surface of the soil. Dead organic matter is quickly broken down and reabsorbed before its nutrients have the chance to be absorbed into the soil. As a result, the organic matter layer in tropical rainforest soils is usually very thin (Hemming, 1985). Tests on rainwater have shown that it is chemically poor both when it first encounters the canopy, and when it leaves the system as groundwater. On the other hand, both stem flow and canopy water have high nutrient levels. This proves that while the system may be very nutrient rich, the vast majority of these nutrients are tightly held within the forest organisms themselves, and not in the soil where it might have the chance to be leached out of the system (Hemming, 1985).

The physical effects of tropical deforestation are also extensive. Without the forest canopy to shield the soil from the heavy tropical rainfalls, soil is directly exposed (Hemming, 1985). Compaction from raindrop impact quickly decreases soil infiltration capacity. This in turn leads to surface erosion as the little remaining topsoil is carried away by runoff, decreasing fertility. Though forests are sometimes burned and the ashes left on the fields in an attempt to transfer some of the valuable nutrients in the biomass to the soil, these are usually also washed away by runoff (Hemming, 1985). It is the lighter clay particles that are usually the first to be carried away by excess runoff in a process called selective erosion, leaving only the heavier sand particles. Sandy soils are less effective at 
holding water and are also less fertile than clay soils (Hemming, 1985). The removal of tree roots which absorbed much of the water that reached the soil in the forest system further decreases the soil's water retention capacity leading to increased incidences of flooding which also damages crops (Hall, 1989). Decreased water retention capacity also decreases soil resistance to drought, increasing crop vulnerability.

Even once sedentary crops are established, the very farming methods employed can contribute to decreasing crop yields and soil fertility, disrupting the nutrient cycle and affecting the biological components of the soil.The use of chemicals such as fertilizers and pesticides in an agricultural system as a replacement for organic materials such as manure causes the microorganisms that rely on those organic materials to die.This in turn causes a decrease in the number of nitrogen fixing bacteria in the already nutrient starved soil leading to a drop in crop yields (Goldsmith, 1990). As yields fall, more and more pesticides must be used to keep nutrients in the soil, in a positive feedback cycle that often ends in crop failure.

The encouraged use of high yield crops for sedentary agriculture further exacerbates the problem because these crops often remove more nutrients and minerals from the soil than unmodified crops. They also deplete the soils of many important minerals that aren't replaced by artificial fertilizers (Goldsmith, 1990). Because of its unsustainable nature, it simply is not practical to clear land to practice sedentary agriculture in tropical rainforest regions.

While the effects of clearing tropical rainforest are usually felt locally, the causes of these patterns are often much farther away, many of which have their roots in the developed world. Technology transfers from the developed, to the developing world have meant that many unskilled worker positions can now be filled by machines (Goodman and Hall, 1990). This has led to unemployment and increasing poverty, which set the stage for government resettlement programs. The majority of the technology transfers have been led by companies in developed countries and international aid programs (Goodman and Hall, 1990). Also, because of the potential profits from the harvesting of resources from the tropical rainforests, many multinational corporations based in developed countries have moved into tropical rainforest regions and are extracting valuable commodities. Unfortunately, the country in which these corporations operate often sees little of the actual profits from these foreign mines or ranches (Bourne, 1978). The majority of these problems are caused by foreign consumer demand. The demand for cash crop imports in the first world propels the clearing of rainforest land for cash crop production in the developing world (Milbrath, 1989). High demand for beef in the USA drives the clearing of rainforest for cattle ranching in much of Latin America (Park, 1992). As can be seen, foreign interests play a major role in the destruction of the rainforests around the world. It is because of this that the developed world has a responsibility to aid in the alleviation of pressure on the world's rainforests, especially in the Amazon region.

Before progress can be made, developed countries must first curb their demand for tropical resources. Because it is foreign demand that is fuelling much of 
the current rainforest destruction, by decreasing the demand, the destruction will also be slowed. For example, if the developed world was less reliant on Brazil for its soybean crop, there would be far less incentive to clear the Amazon in order to harvest it (Skole et al, 1994). This may take the form of widespread education campaigns to inform the public of the conservation issues surrounding the rainforest, or it may be up to the countries themselves to switch to more sustainable alternative imports.

It will also be very important for developed countries to help improve economic conditions in developing countries so that they no longer rely so heavily on exports. This will also decrease their reliance on multinational corporations because foreign investment will no longer be such a crucial part of the economy. This help may come in the form of international aid, or debt relief. If less national profit is used to repay foreign debts, countries such as Brazil would be able to concentrate more on their own sustainable development.

Developed nations can also be a part of the solution by signing treaties such as the International Tropical Timber Agreement that gets producers and consumers to support improved forest management practices and timber processing, as well as conservation. This will help to alleviate pressure on rainforests all over the world, and may further discussion of sustainability issues in other areas of politics. It is unreasonable to expect the developed world to stop using the tropical rain forests altogether, but it is important to switch from unsustainable to sustainable tropical forestry practices
There are many reasons for the settlement of tropical rainforest regions, many of them leading to the clearing of land for unsustainable activities such as sedentary agriculture. While many of the problems associated with tropical rainforest disappearance are local, the developed world has also played a detrimental role. Because of this the developed world must accept responsibility for relieving some of the pressure on tropical regions such as the Amazon. It therefore is of crucial importance that the developed and developing nations work together to ensure that the future of these important regions.

Bibliography:

Bourne, R. (1978). Assault on the Amazon. Camelot Press Ltd: 320 p.

Hall, A. (1989). Developing Amazonia: Deforestation and Social Conflict in Brazil's Carajas Programme. Manchester University Press: 295 p.

Hemming, J. (1985). Man's Impact on Forests and Rivers. Manchester University Press: 222p.

Goldsmith, E. et al. (1990). 5000 Days to Save the Planet. Paul Hamlyn Publishing: 288p.

Goodman, D. and Hall, A. (1990). The Future of Amazonia. The Macmillan Press Ltd: 419 p.

Milbrath, L. (1989). Envisioning a Sustainable Society. Stat University of New York Press. 403p.

Park, C. (1992). Tropical Rainforests. Routledge: $188 \mathrm{p}$.

Skole, D.L. et al.(1994). Physical and human dimensions of deforestation in Amazonia.BioScience, 44: 314 322. 